\title{
Evaluation of clinical outcomes of cemented vs uncemented knee prostheses covered with titanium plasma spray and hydroxyapatite: A minimum two years follow-up
}

\author{
Titanyum plazma spreyi ve hidroksiapatit ile kaplı çimentolu ve çimentosuz diz protezlerinin \\ klinik sonuçlarının değerlendirilmesi: En az iki yıl takip
}

\author{
Karoly Pap (D), MD, Ph.D, ${ }^{1,3}$ Gabor Vasarhelyi(D, MD, ${ }^{1}$ Tamas Gal(D, MD, ${ }^{1,3}$ Gyorgy Nemeth ${ }^{1},{ }^{2}$ \\ Bence Abonyi, MD (D), Laszlo Rudolf Hangody (D, MD, Ph.D, ${ }^{1}$ \\ Gyorgy Mark Hangody (D, MD, Ph.D, ${ }^{1}$ Laszlo Hangody $\left(\mathbb{D}\right.$, MD, D.Sc. ${ }^{1,3}$ \\ 'Department of Orthopedics and Traumatology, Uzsoki Hospital, Budapest, Hungary \\ ${ }^{2}$ SanatMetal Ltd. Eger, Hungary \\ ${ }^{3}$ Department of Traumatology, Semmelweis University, Budapest, Hungary
}

\begin{abstract}
Objectives: In this study, we introduce the SanatSwing cementless total knee prosthesis coated with a combination of titanium plasma spray and hydroxyapatite porous coating and compared its early results to the SanatSwing cemented knee prosthesis.
\end{abstract}

Patients and methods: We compared 278 patients, who underwent total knee replacement between September 2012 and February 2017. A total of 142 patients (Group A; 78 male, 64 female,

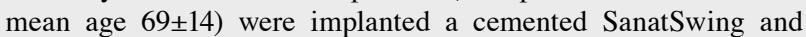
136 patients (Group B; 83 male, 53 female, mean age 59 \pm 10 ), a cementless SanatSwing knee prosthesis was implanted. Implant position and periprosthetic bone conditions were investigated over time on radiographs after a mean follow-up period of two years. Range of motion, pain level, distance of painless walk, and the ability to climb stairs were evaluated.

Results: Significant improvement was observed in both the cemented and uncemented groups when the preoperative scores were compared to the scores of their final visit, but we did not find any difference in measured scores between the cemented and uncemented group. Complication rates were low and almost similar in both groups without any significant difference.

Conclusion: We used the combination of titanium plasma spray and the hydroxyapatite porous coating technique in cementless prostheses. Our results showed us that the novel SanatSwing cementless total knee prosthesis could be a great alternative to cemented total knee arthroplasty.

Keywords: Cementless prosthesis; functional evaluation; hydroxyapatite; knee; titanium plasma spray.

\section{ÖZ}

Amaç: Bu çalışmada, titanyum plazma sprey ve hidroksiapatit gözenekli kaplama kombinasyonu ile kaplanmış SanatSwing çimentosuz total diz protezi tanıtıldı ve erken sonuçları SanatSwing çimentolu diz protezi ile karşılaştırıldı.

Hastalar ve yöntemler: Eylül 2012 - Şubat 2017 arasında total diz replasmanı yapılan 278 hasta karşılaştırıldı. Toplam

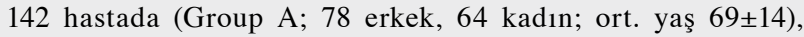
çimentolu SanatSwing diz protezi ve 136 hastada (Group B; 83 erkek, 53 kadın; ort. yaş $59 \pm 10$ ) çimentosuz SanatSwing diz protezi implante edildi. Ortalama iki yıllık takip süresinden sonra radyografilerde implant pozisyonu ve periprostetik kemik koşulları araştırıldı. Hareket açıklığı, ağrı seviyesi, ağrısız yürüyüş mesafesi ve merdiven çıkma yeteneğ $\mathrm{i}$ değerlendirildi.

Bulgular: Ameliyat öncesi skorlar, son ziyaretlerinin skorları ile karşılaştırıldığında hem çimentolu hem de çimentosuz gruplarda belirgin iyileşme gözlendi, ancak çimentolu ve çimentosuz gruplar arasında ölçülen puanlarda bir fark bulunmadı. Her iki grupta da komplikasyon oranları düşük ve neredeyse benzerdi ve aralarında anlamlı bir fark yoktu.

Sonuç: Titanyum plazma spreyi ile hidroksiapatit gözenekli kaplama tekniğinin kombinasyonunu çimentosuz protezlerde kullandık. Elde ettiğimiz sonuçlar bize, yeni SanatSwing çimentosuz total diz protezi serisinin çimentolu total diz artroplastisine mükemmel bir alternatif olabileceğini gösterdi.

Anahtar sözcükler: Çimentosuz protez; fonksiyonel değerlendirme; hidroksiapatit; diz; titaniyum plazma spreyi. 
The overuse of the knee joints and the genetic background can result damage in the hyaline cartilage, mensicus and in the subchondral bone. This may lead to osteoarthritis. In case of severe pain and radilogical deformations arthroplasty is adviced. ${ }^{[1]}$

Total knee arthroplasty (TKA) is an effective method of treatment for advanced osteoarthritis, and leads to substantial improvement in quality of life. ${ }^{[2]}$ For the most part, cemented tibial fixation has been applied and excellent long-term results have been reported. ${ }^{[3]}$ While cemented fixation for remains the gold standard for TKA, aseptic loosening continues to be a common failure mechanism, particularly in young patients. ${ }^{[4]}$ This is why cementless fixation remains of interest to clinicians to apply this method in younger and more active patients, to preserve bone stock, or due to its ease of revision, to avoid complications of cementing, but most importantly, because of the improved long-term survival of the prosthesis. ${ }^{[5-7]}$ The majority of cementless TKA systems have endured limited success predominantly due to failed metal backed patellar components with subsequent metallosis. ${ }^{[8]}$ Osteolysis secondary to tibial and patellar failures have typically required removal and revision of all three components in the knee replacement. ${ }^{[9,10]}$ This is why there has been a growing interest in different prostheses coated methods which can promote osseous ingrowth and consequently more reliable biological fixation. ${ }^{[11,12]}$ Along with methods such as sintered Co-Cr beads, porous titanium alloy, open-cell porous tantalum construct, and fiber-metal mesh, there have been numerous efforts in developing and finding the ideal coating for the cementless prosthesis surface. ${ }^{[13]}$

In our study, we introduce the Sanatmetal cementless total knee prosthesis coated with the combination of titanium plasma spray and hydroxyapatite porous coating and compared its early results with the Sanatmetal cemented knee prosthesis.

\section{PATIENTS AND METHODS}

The study protocol was approved by the Uzsoki Hospital Ethics Committee. A written informed consent was obtained from each patient. The study was conducted in accordance with the principles of the Declaration of Helsinki.

We compared 278 patients who underwent total knee replacement between September, 2012 and February, 2017. A total of 142 (Group A; 78 male, 64 female, mean age $69 \pm 14$ ) patients were implanted a cemented SanatSwing and 136 patients (Group B; 83 male, 53 female, mean age $59 \pm 10$ ), a cementless SanatSwing knee prosthesis was implanted (Figure 1). The inclusion criteria into the uncemented group were good bone quality, relatively young age, and absence of patellofemoral arthritis. All operations were performed by the same two consultant orthopedic surgeons. A tourniquet was used, and an anterior midline incision $11-13 \mathrm{~cm}$ in length was made with a mid-vastus capsular approach. Tibial preparation was performed first. In the uncemented group, only the patella was denervated. All three components were fixed by cementation in the cemented group (Group A), or femoral and tibial components were implanted with a press fit technique in the uncemented group (Group B). The stability of the tibia component was initially increased with two self-cutting screws (25-50 mm length). Component stability was checked manually with the leg in full extension and flexion. Varus and valgus stresses were also tested. On the first postoperative day, patients stood up, began full weight bearing, and continuous passive motion and active exercises were initiated under the supervision of a physiotherapist.

Implant position and periprosthetic bone conditions were investigated over time on radiographs after a mean follow-up period of two years. Patients underwent $\mathrm{X}$-ray examinations
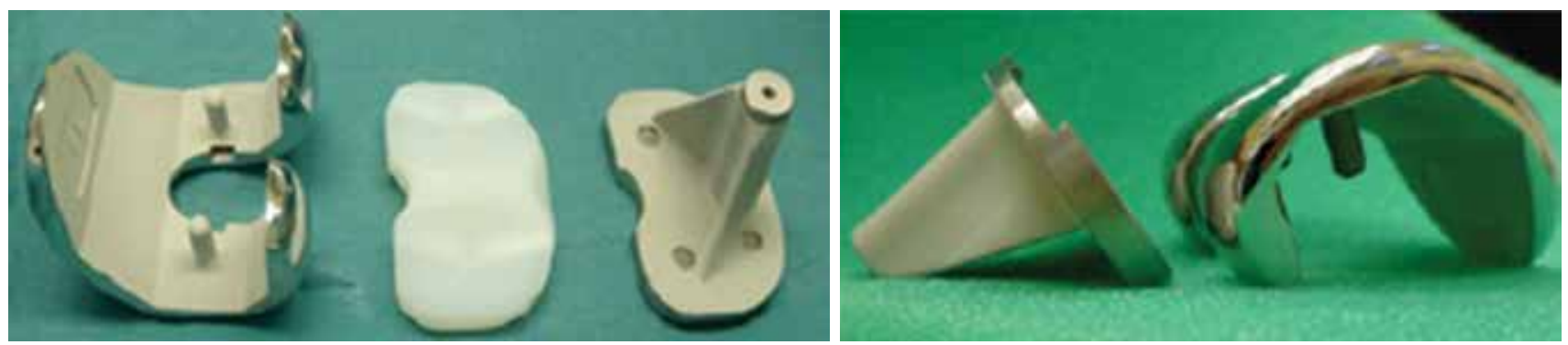

Figure 1. Design of the SanatSwing uncemented prosthesis. 
TABLE

\begin{tabular}{|c|c|c|c|c|c|c|}
\hline \multicolumn{7}{|c|}{ Preoperative data } \\
\hline & \multicolumn{3}{|c|}{ Cemented group $(n=140)^{\star}$} & \multicolumn{3}{|c|}{ Uncemented group $(n=134)^{*}$} \\
\hline & $\mathrm{n}$ & $\%$ & Mean $\pm S D$ & $\mathrm{n}$ & $\%$ & Mean $\pm S D$ \\
\hline Knee society score & & & $48 \pm 12$ & & & $47 \pm 16$ \\
\hline $\begin{array}{l}\text { Pain severity (\%) } \\
\text { None } \\
\text { Mild } \\
\text { Moderate } \\
\text { Severe }\end{array}$ & $\begin{array}{c}- \\
- \\
31 \\
109\end{array}$ & $\begin{array}{c}- \\
- \\
22.1 \\
77.9\end{array}$ & & $\begin{array}{c}- \\
- \\
33 \\
101\end{array}$ & $\begin{array}{c}- \\
- \\
24.6 \\
75.3\end{array}$ & \\
\hline $\begin{array}{l}\text { Walking distance } \\
\text { Can not walk } \\
<1 \mathrm{~km} \text { or half an hour } \\
>1 \mathrm{~km} \text { or half an hour }\end{array}$ & $\begin{array}{c}1 \\
113 \\
26\end{array}$ & $\begin{array}{c}0.7 \\
80.7 \\
18.6\end{array}$ & & $\begin{array}{c}1 \\
119 \\
14\end{array}$ & $\begin{array}{c}0.7 \\
88.8 \\
10.5\end{array}$ & \\
\hline $\begin{array}{l}\text { Stairs } \\
\text { Without support } \\
\text { With support }\end{array}$ & $\begin{array}{c}5 \\
135\end{array}$ & $\begin{array}{c}3.5 \\
96.5\end{array}$ & & $\begin{array}{c}1 \\
133\end{array}$ & $\begin{array}{c}0.7 \\
99.3\end{array}$ & \\
\hline Mean range of motion $\left({ }^{\circ}\right)$ & & & $96.9 \pm 12$ & & & $99.32 \pm 9$ \\
\hline
\end{tabular}

* $2-2$ case were excluded because of septic revision; SD: Standard deviation.

immediately postoperatively and at six weeks, six months, 12 months, and two years postoperatively. At each follow-up visit, anteroposterior (AP) and lateral standing radiographs were obtained. All X-rays were evaluated by an independent examiner.

Range of motion was measured in the early postoperative period during the in-hospital stay $\left(5^{\text {th }}\right.$ postoperative day), at the sixth postoperative week, at the sixth postoperative month, and at the end of the second postoperative year. The patients were asked to measure their pain level in the same periods.
The patients could choose between intense, mild, or no pain. We also registered the distance of painless walk. Patients could choose between less than 30 minutes or $1 \mathrm{~km}$, more than 30 minutes or $1 \mathrm{~km}$ or unlimited painless walking. The ability of climbing stairs with the operated limb was also evaluated. In this case, the patients were questioned only at the third postoperative month and at the end of the first year. The Knee Society (KS) score was also registered preoperatively, at the sixth postoperative months follow up and at the end of the second postoperative year. ${ }^{[14]}$

TABLE II

Clinical results at six months postoperative

\begin{tabular}{|c|c|c|c|c|c|c|}
\hline & \multicolumn{3}{|c|}{ Cemented group $(n=140)^{*}$} & \multicolumn{3}{|c|}{ Uncemented group $(n=134)^{\star}$} \\
\hline & $\mathrm{n}$ & $\%$ & Mean $\pm S D$ & $\mathrm{n}$ & $\%$ & Mean $\pm S D$ \\
\hline Knee society score & & & $64.3 \pm 14$ & & & $65.1 \pm 17$ \\
\hline \multicolumn{7}{|l|}{ Pain severity (\%) } \\
\hline None & 107 & 76 & & 96 & 72 & \\
\hline Mild & 33 & 26 & & 38 & 28 & \\
\hline Moderate & - & - & & - & - & \\
\hline Severe & - & - & & - & - & \\
\hline \multicolumn{7}{|l|}{ Walking distance } \\
\hline Can not walk & 0 & 0 & & 0 & 0 & \\
\hline$<1 \mathrm{~km}$ or half an hour & 25 & 18 & & 28 & 21 & \\
\hline$>1 \mathrm{~km}$ or half an hour & 115 & 82 & & 106 & 79 & \\
\hline \multicolumn{7}{|l|}{ Stairs } \\
\hline Without support & 49 & 35 & & 41 & 31 & \\
\hline With support & 91 & 65 & & 93 & 69 & \\
\hline Mean range of motion $\left({ }^{\circ}\right)$ & & & $107 \pm 17$ & & & $105 \pm 15$ \\
\hline
\end{tabular}

* 2-2 case were excluded because of septic revision; SD: Standard deviation. 
TABLE III

Clinical results at the end of the second postoperative year

\begin{tabular}{|c|c|c|c|c|c|c|}
\hline & \multicolumn{3}{|c|}{ Cemented group $(n=140)^{*}$} & \multicolumn{3}{|c|}{ Uncemented group $(n=134)^{*}$} \\
\hline & $\mathrm{n}$ & $\%$ & Mean $\pm S D$ & $\mathrm{n}$ & $\%$ & Mean $\pm S D$ \\
\hline Knee society score: functional score & & & $79 \pm 17$ & & & $82 \pm 15$ \\
\hline \multicolumn{7}{|l|}{ Pain severity (\%) } \\
\hline None & 114 & 82 & & 116 & 86 & \\
\hline Mild & 26 & 18 & & 19 & 14 & \\
\hline Moderate & - & - & & - & - & \\
\hline Severe & - & - & & - & - & \\
\hline \multicolumn{7}{|l|}{ Walking distance } \\
\hline Can not walk & 0 & 0 & & 0 & 0 & \\
\hline$<1 \mathrm{~km}$ or half an hour & 17 & 12 & & 19 & 14 & \\
\hline$>1 \mathrm{~km}$ or half an hour & 123 & 88 & & 115 & 86 & \\
\hline \multicolumn{7}{|l|}{ Stairs } \\
\hline Without support & 73 & 52 & & 66 & 49 & \\
\hline With support & 68 & 48 & & 68 & 51 & \\
\hline Mean range of motion $\left({ }^{\circ}\right)$ & & & $113 \pm 21$ & & & $116 \pm 23$ \\
\hline
\end{tabular}

* $2-2$ case were excluded because of septic revision; SD: Standard deviation.

The results were compared with a two-tailed t-test. The level of significance used was $p<0.05$. Statistical analysis was performed with SAS statistical software package (SAS/STAT, Software Release 9.1.3., SAS Institute Inc., NC, USA).

\section{RESULTS}

The patients in this study were $69 \pm 14$ years old in Group A and $59 \pm 10$ years old in Group B. The pre(Group A $48 \pm 12$ vs. Group B 47 $\pm 16, p=0.541$ ) and postoperative KS scores (Group A $64.3 \pm 14$ vs. Group B $65.1 \pm 17, p=0.341$ ), walking distance, ability to climb and descend stairs, range of motion (ROM) and VAS pain scores were not significantly different between the two groups (Table 1-3) before surgery, at the sixth postoperative month, and at the end of the second postoperative year visit.

Significant improvement was observed in both the cemented and uncemented groups compared to their preoperative scores of their final visit.
At the end of the second year visit, the mean KS score (Group A preoperative $48 \pm 12$ vs. Group A postoperative second year $79 \pm 17, p=0.0013$, Group B preoperative $47 \pm 16$ vs. Group B postoperative second year $82 \pm 15, \mathrm{p}=0.0025$ ) $\mathrm{ROM}$ (Group A preoperative $96.9 \pm 12$ vs. Group A postoperative second year $113 \pm 21, \mathrm{p}=0.031$, Group B preoperative $99.32 \pm 9$ vs. Group B postoperative second year 116 $\pm 23, p=0.029$ ), improved significantly in both groups compared to the preoperative scores. At the final follow-up examination, patient satisfaction was similar. Mild pain remained in 26 cases $(18 \%)$ in group A and in 19 cases (14\%) in group B.

The mean operation time in Group A was $55 \pm 11$ minutes versus $69 \pm 19$ minutes in Group B. A significant difference was observed $(\mathrm{p}=0.031)$.

Complication rates were low and almost similar in both groups without any significant difference (Table 4). Two knees in both groups suffered septic loosening; these were treated with two-step revision

TABLE IV

\begin{tabular}{|c|c|c|c|c|c|}
\hline \multicolumn{6}{|c|}{ Complications } \\
\hline & \multirow{2}{*}{\multicolumn{2}{|c|}{$\frac{\text { Cemented group }}{(n=140)}$}} & \multirow{2}{*}{\multicolumn{2}{|c|}{$\frac{\text { Uncemented group }}{(n=134)}$}} & \multirow[b]{3}{*}{$p$} \\
\hline & & & & & \\
\hline & $\mathrm{n}$ & $\%$ & $\mathrm{n}$ & $\%$ & \\
\hline Wound disorder, hemarthrosis & 20 & 14 & 17 & 12 & 0.619 \\
\hline Septic revision & 2 & 1.4 & 2 & 1.5 & 0.887 \\
\hline Deep venous thrombosis & 2 & 1.4 & 1 & 0.7 & 0.355 \\
\hline Manipulation under anesthesia & 5 & 3.5 & 4 & 2.9 & 0.389 \\
\hline Open lysis of adhesions & 2 & 1.4 & 2 & 1.5 & 0.671 \\
\hline
\end{tabular}



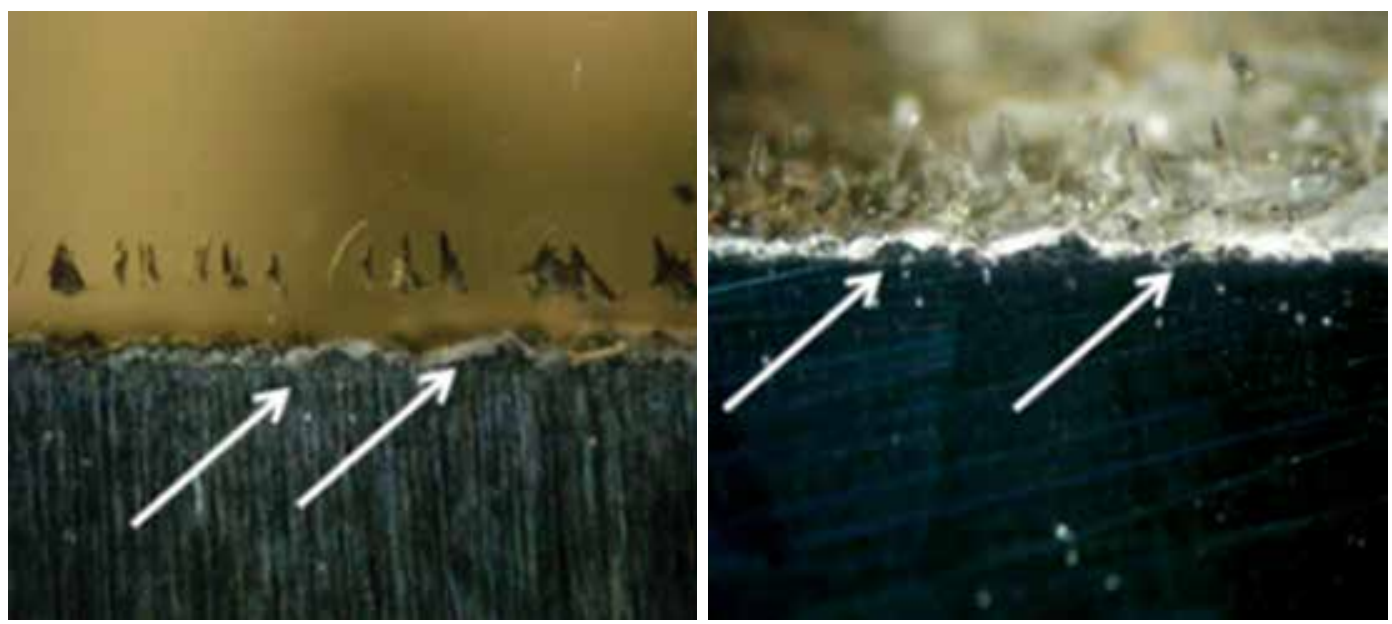

Figure 2. Cross-sections of removed uncemented tibial plateau of the prosteses. The bony incorporation is visible on the side of the bone-prosthesis border (marked with arrow).

surgeries. After the removal of a four month old cementless prosthesis, we analyzed the bony integration into the femoral and tibial prosthesis surfaces. Total bony incorporation was found on the side of the bone-prosthesis border (Figure 2). No aseptic loosening was found in either group $\mathrm{A}$ or group B. In two cases in group B, radiolucent lines were found by our examiners, but no migration of the tibial or the femoral components were visible.

The same results were observed in cases of minor complications. No significant differences were found in cases of wound disorders (Group A 14\% vs. Group B $12 \%, \mathrm{p}=0.619$ ), deep vein thrombosis (Group A $1.4 \%$ vs Group B 1.5\%, $\mathrm{p}=0.655)$ and open lysis of adhesions (Group A 1.4\% vs. Group B 1.5\%, p=0.671). Mean postoperative blood loss (including intraoperative blood loss and blood collected in a suction drain) was $1,286.9 \pm 428.1$ (range from $215-1,880 \mathrm{~mL}$ ) in the uncemented group and $921.9 \pm 316.1 \mathrm{~mL}$ (range from 285-2510 mL). This difference was significant (paired t-test $\mathrm{p}=0.0236$ ).

\section{DISCUSSION}

The theoretical advantages of cementless TKA include the potential to preserve bone stock and avoid cement debris, but most importantly, the potential to achieve lasting, biological fixation of the implant to the bone with shorter operative time.

Therefore, there has been a reemergence of the development and use of cementless TKA. Recent shortterm trials have demonstrated that modern cementless TKA has comparable survivability and functional outcomes to cemented prostheses. ${ }^{[4]}$ However, more prospective, randomized trials are needed to clearly delineate any differences between these two fixation options. ${ }^{[15]}$ In our study, we found neither functional nor radiological difference between the cemented and cementless knee prosthesis. We implanted SanatSwing cementless TKA in a total of 136 patients. In these 136 patients, two septic complications were observed, the same amount as in the cemented group. No aseptic loosening was observed in either of the groups during the examination period.

The operation time was significantly shorter in the uncemented group, because of the lack of the setting time of the cement. The shorter operation time means the opened tissues can be closed earlier, which could decrease the rate of septic complications.

Once osseointegration has occurred, it is highly unlikely that loosening will present, except due to lysis or sepsis. With an increasing number of younger and more active patients seeking TKA, ${ }^{[16]}$ surgeons are looking for a more physiological bond.

Tibial baseplate loosening is one of the most common disadvantages of cementless TKA implantations ${ }^{[4]}$ In two cases in group B, radiolucent lines were visible under the tibial component, but this did not disturb the patients in their daily activity. The patients had full pain-free active and passive ROM.

We used the combination of titanium plasma spray and the hydroxyapatite porous coating technique in cementless protheses for the first time in literature. We found normal osseointegration with the formation of a biological interface between the bone and the prosthetic components. This was also observed after histological examinations of the removed septic knee prostheses. The operation 
time was significantly shorter in the uncemented group. This was most likely due to the sparing of the cementing time.

In conclusion; the novel SanatSwing cementless total knee prosthesis could be a great alternative for cemented total knee arthroplasty. The results thus far are promising, however we would like to increase the number of cases and report long-term follow-up results.

\section{Declaration of conflicting interests}

The authors declared no conflicts of interest with respect to the authorship and/or publication of this article.

\section{Funding}

The design and development of the prosthesis was supported by SanatMetal Ltd.

\section{REFERENCES}

1. Atik OS, Erdoğan D, Seymen CM, Bozkurt HH, Kaplanoğlu GT. Is there crosstalk between subchondral bone, cartilage, and meniscus in the pathogenesis of osteoarthritis? Eklem Hastalik Cerrahisi 2016;27:62-7.

2. Ethgen $\mathrm{O}$, Bruyère $\mathrm{O}$, Richy $\mathrm{F}$, Dardennes $\mathrm{C}$, Reginster JY. Health-related quality of life in total hip and total knee arthroplasty. A qualitative and systematic review of the literature. J Bone Joint Surg Am 2004;86:963-74.

3. Kane RL, Saleh KJ, Wilt TJ, Bershadsky B. The functional outcomes of total knee arthroplasty. J Bone Joint Surg Am 2005;87:1719-24.

4. Kim YH, Park JW, Lim HM, Park ES. Cementless and cemented total knee arthroplasty in patients younger than fifty five years. Which is better? Int Orthop 2014;38:297-303.

5. Kim YH, Kim JS, Choe JW, Kim HJ. Long-term comparison of fixed-bearing and mobile-bearing total knee replacements in patients younger than fifty-one years of age with osteoarthritis. J Bone Joint Surg Am 2012;94:866-73.

6. Lombardi AV Jr, Berasi CC, Berend KR. Evolution of tibial fixation in total knee arthroplasty. J Arthroplasty
2007;22:25-9.

7. Kim YH, Kim JS, Park JW, Joo JH. Comparison of the low contact stress and press fit condylar rotating-platform mobile-bearing prostheses in total knee arthroplasty: a prospective randomized study. J Bone Joint Surg Am 2011;93:1001-7.

8. Porter M, Borroff M, Gregg P, MacGregor A, Tucker K. National Joint Registry for England, Wales, Northern Ireland and the Isle of Man. 9th Annual Report (April 2012 - March 2013). Available from: www.new.njrcentre. org.uk/njrcentre/Reports,PublicationsandMinutes/Annualreports/Archivedannualreports/tabid/87/Default.aspx 2016.

9. Nolan JF, Bucknill TM. Aggressive granulomatosis from polyethylene failure in an uncemented knee replacement. J Bone Joint Surg Br 1992;74:23-4.

10. Berry DJ, Wold LE, Rand JA. Extensive osteolysis around an aseptic, stable, uncemented total knee replacement. Clin Orthop Relat Res 1993;293:204-7.

11. Park JW, Kim YH. Simultaneous cemented and cementless total knee replacement in the same patients: a prospective comparison of long-term outcomes using an identical design of NexGen prosthesis. J Bone Joint Surg [Br] 2011;93:1479-86.

12. Baker PN, Khaw FM, Kirk LM, Esler CN, Gregg PJ. A randomised controlled trial of cemented versus cementless press-fit condylar total knee replacement: 15-year survival analysis. J Bone Joint Surg Br 2007;89:1608-14.

13. Davis JR. Coatings. In: Davies JR, editor. Handbook of Materials for Medical Devices. Ohio: ASM International; 2003. p. 179-94.

14. Insall JN, Dorr LD, Scott RD, Scott WN. Rationale of the Knee Society clinical rating system. Clin Orthop Relat Res 1989;248:13-4.

15. Khaw FM, Kirk LM, Morris RW, Gregg PJ. A randomised, controlled trial of cemented versus cementless press-fit condylar total knee replacement. Ten-year survival analysis. J Bone Joint Surg Br 2002;84:658-66.

16. Kurtz SM, Lau E, Ong K, Zhao K, Kelly M, Bozic KJ. Future young patient demand for primary and revision joint replacement: national projections from 2010 to 2030. Clin Orthop Relat Res 2009;467:2606-12. 